Terr. Atmos. Ocean. Sci., Vol. 17, No. 4, 933-950, December 2006

\title{
Methane Venting in Gas Hydrate Potential Area Offshore of SW Taiwan: Evidence of Gas Analysis of Water Column Samples
}

\author{
Tsanyao Frank Yang ${ }^{1, ~ *}$, Pei-Chuan Chuang ${ }^{1}$, Saulwood Lin ${ }^{2}$, Ju-Chin Chen ${ }^{2}$, \\ Yunshuen Wang ${ }^{3}$, and San-Hsiung Chung ${ }^{3}$
}

(Manuscript received 8 September 2006, in final form 4 December 2006)

\begin{abstract}
Water column samples were collected systematically in several potential gas hydrate areas offshore of SW Taiwan for analysis of dissolved gases. Some these samples show unusually high dissolved methane concentrations at sites $\mathrm{A}, \mathrm{B}, \mathrm{C}$, and $\mathrm{H}$ of cruise ORI-765. The profiles of helium concentrations in the dissolved gases of the water column also exhibit consistent results with an increasing trend toward the seafloor. The ${ }^{3} \mathrm{He} /{ }^{4} \mathrm{He}$ ratios range from 0.2 to 0.4 times that of the atmospheric air ratio after air correction, which fall in the range of typical crustal gas composition and are similar to those of on-shore mud volcanoes in SW Taiwan. This indicates that gases are venting actively from the seafloor in the region and may share similar gas sources to on-shore mud volcanoes. The venting gases are considered to have originated from dissociation of gas hydrates and/or a deeper gas reservoir.
\end{abstract}

(Key words: Gas hydrate, Methane venting, Water column, Helium, Radon)

\section{INTRODUCTION}

The northern part of the Taiwan-Luzon Arc, which formed in response to the subduction of the South China Sea plate underneath the Philippine Sea plate, is currently colliding with the Eurasian continental plate. This collision has propagated progressively southward, thus the northern part of the arc has already been accreted onto the continental margin resulting in the formation of an accretionary prism in southwestern Taiwan (Teng 1990; Huang et al. 1997;

\footnotetext{
${ }^{1}$ Department of Geosciences, National Taiwan University, Taipei, Taiwan, ROC

2 Institute of Oceanography, National Taiwan University, Taipei, Taiwan, ROC

${ }^{3}$ Central Geological Survey, MOEA, Taipei, Taiwan, ROC

* Corresponding author address: Prof. Tsanyao Frank Yang, Department of Geosciences, National Taiwan University, Taipei, Taiwan, ROC; E-mail: tyyang@ntu.edu.tw
} 
Liu et al. 1997). Numerous mud volcanoes and diapiric intrusion have been found along tectonic structures both on-shore and offshore of southwestern Taiwan (e.g., Chow et al. 2000; Yang et al. 2004; Chiu et al. 2006). The gases vented from on-shore mud volcanoes are dominated by methane (Yang et al. 2004) and exhibit mainly typical crustal helium isotopic ratios, i.e., lower ${ }^{3} \mathrm{He} /{ }^{4} \mathrm{He}$ ratio ( $<0.2$ times of $R_{A}, R_{A}$ is the air ratio; Yang et al. 2003b). However, the composition and flux of gases released from the Chung-lun mud pool showed significant variation and are considered to be controlled by tectonic structures (Yang et al. 2003b) and related to the changes of local stress and strain (Yang et al. 2006).

Gas hydrates are quite common and well-known from accreted sediments at plate collision zones (e.g., Cascadian margin and the Nankai Trough), as well as from sedimentary sequences at passive margins (Kvenvolden 1998; Sloan 1998; Kvenvolden and Lorenson 2000; Lorenson and Collett 2000; Colwell et al. 2004; Matsumoto 2004): they have been considered a potential energy resource for the future. Geophysical surveys show that intensive Bottom Simulating Reflectors (BSRs), that are considered to be one of the most effective indicators of existing gas hydrate in a given region, are distributed in a wide area of offshore southwestern Taiwan (Chi et al. 1998; Schnürle 1999, 2002; Liu et al. 2004, 2006). This indicates that abundant gas hydrate deposits may exist in the sediments of both the passive and active continental margins offshore of SW Taiwan. In addition to the BSRs, geological and geochemical data also support the interpretation that gas hydrates may exist in southwestern Taiwan continental margin sediments (Chao and You 2006; Chuang et al. 2006; Horng and Chen 2006; Huang et al. 2006; Jiang et al. 2006; Lin et al. 2006; Oung et al. 2006; Shyu et al. 2006). Hence, the region has been considered a gas hydrate potential area.

Gas hydrates beneath the ocean floor may become unstable as a result of changing temperature and pressure conditions and in particular if warm fluids are moving through highly permeable faults (Pecher 2002). As a result, the high pressure fluids generated by gas hydrate dissociation will permeate upward to the seafloor. Furthermore, according to high resolution seismic data, a chimney structure could provide fluids one of the main migration pathways in gas hydrate bearing layers (Pecher 2002; Wood et al. 2002). Such a mechanism can explain the occurrence of submarine mud volcanoes in the gas hydrate potential areas of offshore SW Taiwan, which is tectonically active (e.g., Chiu et al. 2006). Given this interpretation, numerous active venting sites along some tectonic structures in this area may be expected to exist in the area. The venting gases would be derived from the dissociation of gas hydrates and would enrich the concentration of dissolved gas in nearby seawaters. To examine possible venting in offshore southwestern Taiwan, we systematically collected water column samples from different water depths to analyze the dissolved methane and rare gases (helium and radon) composition. Some anomalously high dissolved gas concentrations in seawaters were found at some sites, and are consistent with other geological/geochemical observations, indicating that there is a high methane flux and active venting in this area.

\section{SAMPLING AND ANALYSIS}

We systematically collected seawater samples at different depths using a CTD Rosette 
sampler during cruise OR1-765 from September 3 to 9, 2005. In total 30 stations were sampled at both the passive margin and active margin off SW Taiwan (Fig. 1). The water depths of sampling sites range from 139 to $1799 \mathrm{~m}$ (Table 1). In general we collected 10 samples for each station. However, we discarded some samples because of too shallow water depths and a leaking problem.

Water samples were transferred immediately to three containers for different analysis. We conducted dissolved methane and radon gas analysis on board. Water samples were stored in low permeability glass bottles and brought back to a shore-based laboratory for helium concentration and isotopic analysis. The sampling and analysis procedure/flow chart is shown in Fig. 2.

We have adopted the method described by Lammers and Suess (1994) for the on board analysis of dissolved methane. About $1200 \mathrm{ml}$ of seawater was put into a flask set in an ultrasonic bath, and connected to two other flasks serving as a water reservoir and trap, and connected to a vacuum for gas extraction (Fig. 2). Detailed procedures of gas extraction are de-

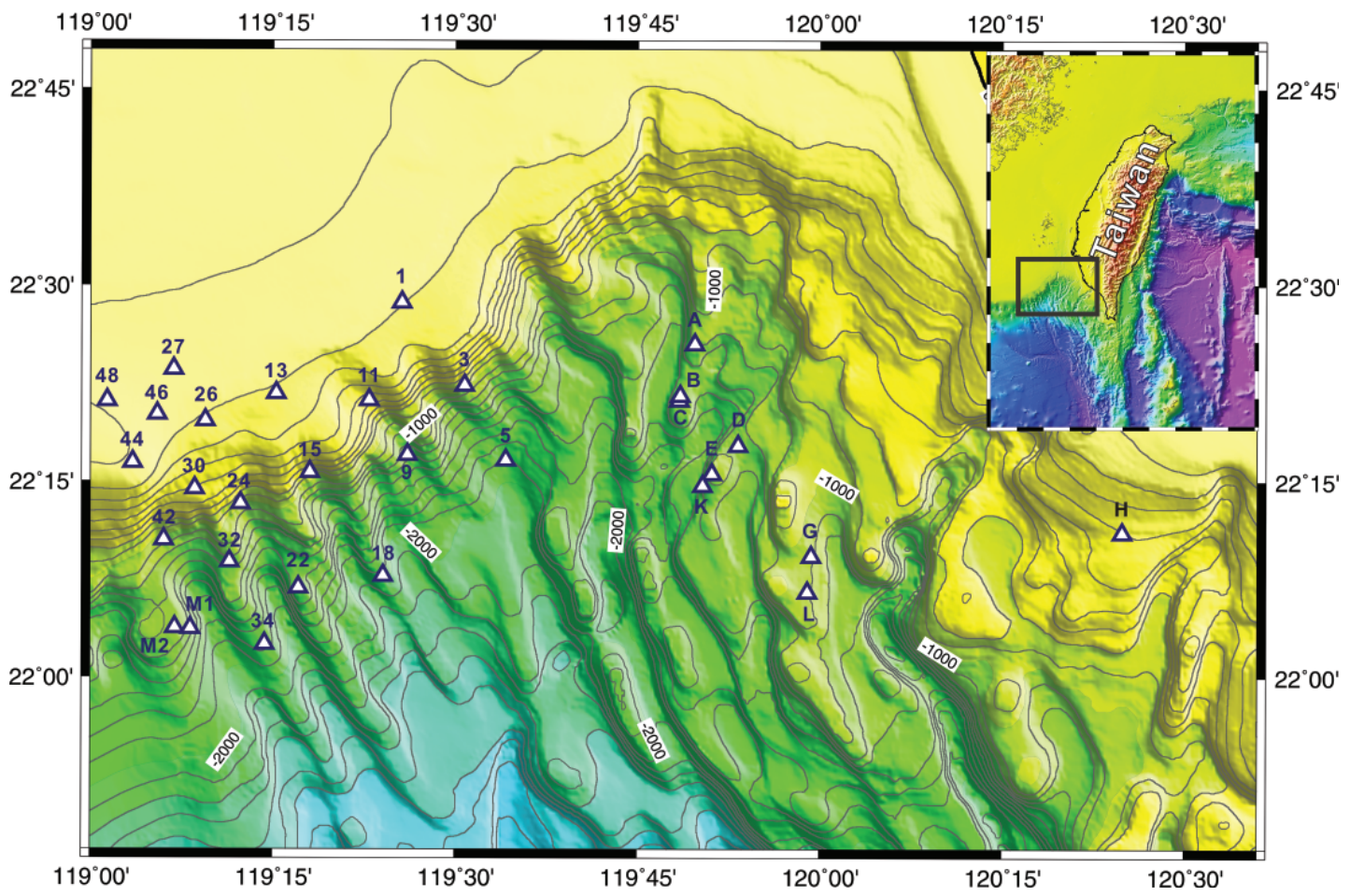

Fig. 1. Bathymetric map and sampling sites of cruise OR1-765 in this study. The inset shows the study area in southwestern Taiwan. 
Table 1. Location and bottom depth of sampling stations together with sampling depth in this study.

\begin{tabular}{|c|c|c|c|}
\hline Station & Location & $\begin{array}{c}\text { Bottom } \\
\text { depth }(\mathrm{m})\end{array}$ & Sampling depth (m) \\
\hline A & $22^{\circ} 25.61^{\prime} \mathrm{N}, 119^{\circ} 49.69^{\prime} \mathrm{E}$ & 1030 & $5,100,250,400,700,800,850,900,950,1000$ \\
\hline $\mathrm{B}$ & $22^{\circ} 21.49^{\prime} \mathrm{N}, 119^{\circ} 48.48^{\prime} \mathrm{E}$ & 1106 & $5,100,300,500,750,880,930,980,1030,1080$ \\
\hline $\mathrm{C}$ & $22^{\circ} 21.18^{\prime} \mathrm{N}, 119^{\circ} 48.88^{\prime} \mathrm{E}$ & 1221 & $5,170,340,510,680,850,1000,1050,1100,1150$ \\
\hline $\mathrm{D}$ & $22^{\circ} 17.80^{\prime} \mathrm{N}, 119^{\circ} 53.22^{\prime} \mathrm{E}$ & 1165 & $5,100,300,500,700,810,860,910,960,1110$ \\
\hline $\mathrm{E}$ & $22^{\circ} 15.54^{\prime} \mathrm{N}, 119^{\circ} 51.14^{\prime} \mathrm{E}$ & 1078 & $5,100,500,920,970$ \\
\hline G & $22^{\circ} 09.25^{\prime} \mathrm{N}, 119^{\circ} 59.28^{\prime} \mathrm{E}$ & 1105 & $5,100,300,500,700,810,860,910,960,1010$ \\
\hline $\mathrm{H}$ & $22^{\circ} 11.07^{\prime} \mathrm{N}, 120^{\circ} 22.09^{\prime} \mathrm{E}$ & 407 & $5,20,50,80,130,180,230,280,330,380$ \\
\hline $\mathrm{K}$ & $22^{\circ} 14.64^{\prime} \mathrm{N}, 119^{\circ} 50.39^{\prime} \mathrm{E}$ & 1291 & $5,360,720,900,1070,1120,1170,1220,1270$ \\
\hline $\mathrm{L}$ & $22^{\circ} 06.69^{\prime} \mathrm{N}, 119^{\circ} 59.11^{\prime} \mathrm{E}$ & 1070 & $5,500,700,900,950,1000,1050$ \\
\hline 1 & $22^{\circ} 28.68^{`} \mathrm{~N}, 119^{\circ} 25.59^{\prime} \mathrm{E}$ & 191 & $5,15,30,50,100,120,140,160,175$ \\
\hline 3 & $22^{\circ} 22.41^{\prime} \mathrm{N}, 119^{\circ} 30.76^{\prime} \mathrm{E}$ & 886 & $5,100,300,500,610,660,710,760,810$ \\
\hline 5 & $22^{\circ} 16.62^{\prime} \mathrm{N}, 119^{\circ} 34.31^{\prime} \mathrm{E}$ & 1925 & $5,100,400,800,1200,1650,1700,1750,1800$ \\
\hline 9 & $22^{\circ} 17.00^{\prime} \mathrm{N}, 119^{\circ} 26.08^{\prime} \mathrm{E}$ & 1506 & $5,100,400,800,1000,1250,1300,1350,1400,1440$ \\
\hline 11 & $22^{\circ} 21.05^{\prime} \mathrm{N}, 119^{\circ} 23.13^{\prime} \mathrm{E}$ & 756 & $5,100,200,250,300,350,400,450,500,530$ \\
\hline 13 & $22^{\circ} 21.59^{\prime} \mathrm{N}, 119^{\circ} 15.48^{\prime} \mathrm{E}$ & 225 & $5,15,30,100,120,140,160,180,200$ \\
\hline 15 & $22^{\circ} 15.66^{\prime} \mathrm{N}, 119^{\circ} 18.27^{\prime} \mathrm{E}$ & 989 & $5,100,200,300,400,500,600,850,900$ \\
\hline 18 & $22^{\circ} 07.74^{\prime} \mathrm{N}, 119^{\circ} 24.18^{\prime} \mathrm{E}$ & 1799 & $5,100,400,700,1000,1300,1600,1650,1700$ \\
\hline 22 & $22^{\circ} 06.89^{\prime} \mathrm{N}, 119^{\circ} 19.09^{\prime} \mathrm{E}$ & 1125 & $5,200,800,900,950,1000,1050,1100$ \\
\hline 24 & $22^{\circ} 13.30^{\prime} \mathrm{N}, 119^{\circ} 12.37^{\prime} \mathrm{E}$ & 810 & $5,100,200,300,400,500,600,700,750,800$ \\
\hline 26 & $22^{\circ} 19.56^{\prime} \mathrm{N}, 119^{\circ} 09.43^{\prime} \mathrm{E}$ & 223 & $5,15,30,50,100,120,140,160,180,200$ \\
\hline 27 & $22^{\circ} 23.68^{\prime} \mathrm{N}, 119^{\circ} 06.92^{\prime} \mathrm{E}$ & 140 & $5,35,70,105,135$ \\
\hline 30 & $22^{\circ} 14.41^{\prime} \mathrm{N}, 119^{\circ} 08.72^{\prime} \mathrm{E}$ & 523 & $5,25,50,100,150,200,250,300,350,400$ \\
\hline 32 & $22^{\circ} 08.85^{\prime} \mathrm{N}, 119^{\circ} 11.48^{\prime} \mathrm{E}$ & 1257 & $5,100,300,500,700,900,1050,1130,1180,1230$ \\
\hline 34 & $22^{\circ} 02.46^{`} \mathrm{~N}, 119^{\circ} 14.56^{\prime} \mathrm{E}$ & 1688 & $5,100,300,500,700,900,1100,1400,1450,1500$ \\
\hline 42 & $22^{\circ} 10.47^{\prime} \mathrm{N}, 119^{\circ} 05.76^{\prime} \mathrm{E}$ & 1136 & $5,100,300,500,700,900,950,1000,1050,1100$ \\
\hline 44 & $22^{\circ} 16.48^{\prime} \mathrm{N}, 119^{\circ} 03.54^{\prime} \mathrm{E}$ & 168 & $5,40,80,120,160$ \\
\hline 46 & $22^{\circ} 20.12^{\prime} \mathrm{N}, 119^{\circ} 05.60^{\prime} \mathrm{E}$ & 156 & $5,35,70,105,140$ \\
\hline 48 & $22^{\circ} 21.15^{\prime} \mathrm{N}, 119^{\circ} 01.47^{\prime} \mathrm{E}$ & 139 & $5,35,70,105,105,135$ \\
\hline M1 & $22^{\circ} 03.69^{\prime} \mathrm{N}, 119^{\circ} 08.29^{\prime} \mathrm{E}$ & 1379 & $5,200,400,600,1000,1200,1250,1300,1350$ \\
\hline M2 & $22^{\circ} 03.75^{\prime} \mathrm{N}, 119^{\circ} 06.99^{\prime} \mathrm{E}$ & 1338 & $5,200,400,600,800,1000,1170,1230,1270,1320$ \\
\hline
\end{tabular}



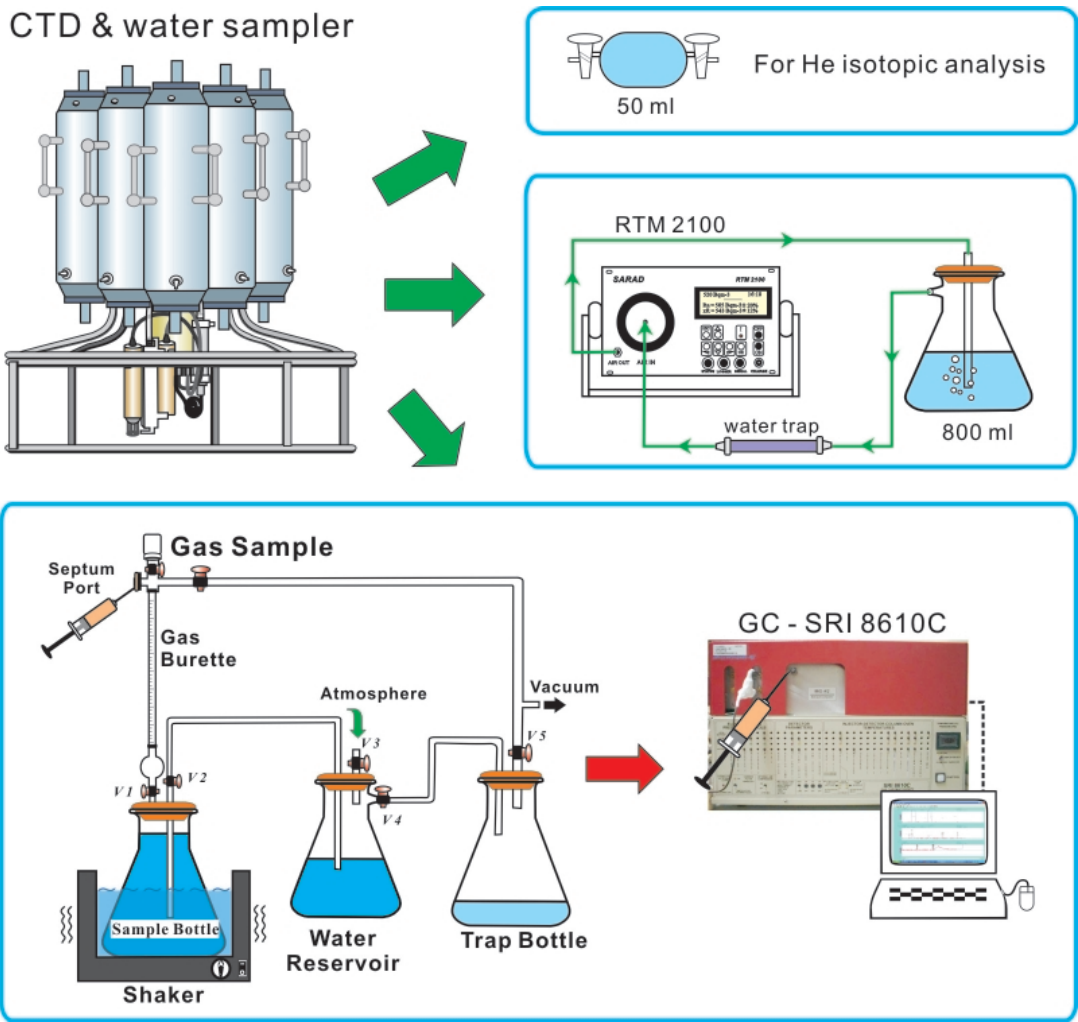

Fig. 2. Flow chart illustrating the sampling method and procedure used for dissolved gases analysis in water samples. Seawater samples were transferred immediately into three different containers for helium, radon and methane analysis. Radon and methane analysis were carried out immediately after appropriate handling for gas extraction on board. Analyses of helium concentration and isotopic composition were performed at a shore based laboratory. See text for detailed description.

scribed by Chuang (2006). The extracted gas was then introduced by a gas tight syringe into a gas chromatograph (GC) (SRI 8610C) equipped with thermal conductivity (TCD) and flame ionization (FID) detectors. Different components of the gas were separated in the GC (injection temperature $30^{\circ} \mathrm{C}$, held isothermal for 2 minutes, ramped to $250^{\circ} \mathrm{C}$ at $120^{\circ} \mathrm{C} \mathrm{min}{ }^{-1}$ ). The system utilizes hydrogen as the carrier gas. Hydrogen was supplied by a cylinder tank for use in the FID and TCD. In general, the methane gas analyzed in this system has analytical errors of less than 5\% with low detection and quantification limits (Lee et al. 2005). Results of dissolved methane concentrations are reported relative to the volume of seawater from which the 
gases were extracted (i.e., nanoliters of gas per liter of seawater $\left[\mathrm{nL} \mathrm{L} \mathrm{L}^{-1}\right]$ ).

Water radon concentrations were determined using a radon detector (RTM2100, SARAD) equipped with an internal pump. Radon gas was extracted with a pump speed of 3 liter min $^{-1}$ from a water sample of ca. $800 \mathrm{ml}$ in a closed loop (Fig. 2). The detection limit and error of radon concentration are similar to those described in soil gases (Fu et al. 2005; Yang et al. 2005b; Walia et al. 2005a).

Pre-evacuated low permeability glass bottles with two evacuated stopcocks at both ends were used for collecting the representative seawaters for the measurement of their helium gas compositions. The seawater samples were transferred into the glass bottles on board right after being collected by Niskin bottles at different depths. ${ }^{3} \mathrm{He} /{ }^{4} \mathrm{He}$ and ${ }^{4} \mathrm{He} /{ }^{20} \mathrm{Ne}$ ratios were measured using the Micromass 5400 noble-gas mass spectrometer with dual collectors at the Department of Geosciences, National Taiwan University. The system includes a two-stage purification line and a cryogenic pump with charcoal trap. The gas sample first passes through the first-stage purification line to remove most active gases (including $\mathrm{H}_{2} \mathrm{O}, \mathrm{CO}_{2}, \mathrm{~N}_{2}, \mathrm{O}_{2}, \mathrm{H}_{2}$, hydrocarbon, and sulfur gases etc.) and heavy noble gases ( $\mathrm{Ar}, \mathrm{Kr}$, and $\mathrm{Xe}$ ). The sample is then allowed to enter the second-stage purification line for further purification. It includes a Ti-sponge furnace, charcoal trap with liquid nitrogen, and SEAS Ti-Zr getters. At this stage all the active gases should be totally removed and, the purified gas is trapped into a cryogenic pump at $15^{\circ} \mathrm{K}$. Lastly, helium and neon are released by step-wisely increasing temperature to 34 and $70^{\circ} \mathrm{K}$, respectively, to be sequentially admitted into the mass spectrometry for the determination of isotopic compositions. Air is routinely run as a standard for calibration. A $20 R_{A}$ pure helium gas standard is also prepared and run as a working standard to reduce the analytical errors. In general, the total errors on the ratios are less than 2 and 5\% in one sigma standard deviation, respectively, for ${ }^{3} \mathrm{He} /{ }^{4} \mathrm{He}$ and ${ }^{4} \mathrm{He} /{ }^{20} \mathrm{Ne}$. Details of the procedures are found in Yang et al. (2005a).

\section{RESULTS AND DISCUSSION}

\subsection{Very Low Radon Concentration}

Variations of radon concentrations have been widely interpreted as a useful precursor of earthquake and magmatic activity (e.g., Segovia et al. 2003; Chyi et al. 2005; Cigolini et al. 2005; Walia et al. 2005b; Yang et al. 2005b; Imme et al. 2006). We can observe higher radon concentrations wherever there is a higher flux of carrier gases at fault zones or hydrothermal areas. Initially we expected to observe high radon concentrations, especially at sites with high methane flux (e.g., Chuang et al. 2006). However, in this survey, we did not measure any radon concentration in seawater higher than $50 \mathrm{~Bq} \mathrm{~m}^{-3}$, which is the background radon concentration of ocean and tap water used. This was true even at the site A, which exhibits the highest methane flux.

Recently, Schubert et al. (2005) used the high partitioning coefficients between non-aqueous phase-liquids (NAPLs) and air/water to infer the presence of subsurface NAPL. Radon concentrations are always higher in soil gas than in gases exhaling from mud volcanoes in SW Taiwan (T. F. Yang, unpublished data). This implies that the presence of NAPL residues in 
methane dominated mud volcano gases that may absorb radon gas. Under such conditions, radon concentrations are always lower than in $\mathrm{CO}_{2}$-dominated natural gases, even lower than the background concentrations of soil gases. In addition, the gas venting in the off-shore region may have a same similar source as the on-shore mud volcanoes (see discussion below). This may be able to explain why no high radon concentrations were found in this study.

\subsection{Very High Methane Concentration}

The dissolved methane concentrations were determined for a total of 266 samples and the results are shown in Table 2. Most samples do not show unusual methane concentrations. However, some samples show very high methane concentration, ranging up to $115356 \mathrm{~nL} \mathrm{~L}^{-1}$. For comparison, the equilibrium value of methane with respect to its current atmospheric content is $57 \mathrm{~nL} \mathrm{~L}^{-1}$. Background methane concentrations of $<20 \mathrm{~nL} \mathrm{~L}^{-1}$ are normally found in deep oceans (Scranton and Brewer 1978).

Figure 3 shows profiles of dissolved methane concentration with depth for each site. High methane concentrations are observed at sites A, B, C, H, and 30 (Figs. 3a, f). It is interesting to note that site 30 is located at a passive margin setting (Fig. 1) and its high methane concentration (233 nL L $\left.\mathrm{nL}^{-1}\right)$ occurred at shallow water depth $(25 \mathrm{~m})$ (Figs. 3d, f). Sites 48 and B, C, H likewise exhibit this shallow enrichment (Figs. 3e, f). Such shallow methane enrichment may be due to bacteria activity in seawater close to the surface. This result is similar to the recent work of Chen and Tseng (2006) in this area.

In contrast, sites A, B, C, and $\mathrm{H}$ exhibiting high methane concentrations are all located in the active margin in this study. The dissolved methane concentrations of seawater at those sites increase significantly with depth (Figs. 3a, f). Extreme methane concentrations have been reported in both bottom water and cored sediments at those sites (Chuang et al. 2006); in addition, a very high sulfate reduction rate and shallow sub-bottom depth of the sulfate-methane-interface have also been observed (Chuang et al. 2006; Lin et al. 2006). This suggests venting of methane at very high rates at these sites.

\subsection{High Helium Concentration and Low Helium Isotopic Ratios}

Helium and its isotopes are chemically inert, making them very useful in tracing the sources of submarine vent fluids. Primordial helium is degassed from the mantle with a high ${ }^{3} \mathrm{He} /{ }^{4} \mathrm{He}$ ratio, and is considered as an excellent tracer of hydrothermally derived fluids (e.g., Ozima and Podosek 2002). Radiogenic helium, ${ }^{4} \mathrm{He}$, is steadily produced by radioactive decay of radioactive elements $(\mathrm{U}, \mathrm{Th})$ within the sediments. It makes isotopic composition distinctly different from the injection of ${ }^{3} \mathrm{He}$ from hot vents at spreading centers (e.g., Poreda and Craig 1989; Lupton et al. 1998). ${ }^{4} \mathrm{He}$ is therefore a unique cold-vent tracer that can be used to detect non-hydrothermal seep signals (Schlosser and Winckler 2002). Suess et al. (1999) suggested that excess helium and some other anomalous water chemistry in near bottom water are the result of the injection from vent fluids.

Twenty-six representative samples were analyzed for helium concentrations and isotopicratio analysis. The results range from 115 to $848 \mathrm{~nL} \mathrm{~L}^{-1}$ and 0.40 to $0.99 R_{A}$, for helium concentrations and ${ }^{3} \mathrm{He} /{ }^{4} \mathrm{He}$ ratios of dissolved gases in seawaters, respectively (Table 3 ). 
Table 2. Dissolved methane concentrations of water column samples of cruise OR1-765.

\begin{tabular}{|c|c|c|c|c|c|c|c|c|c|c|c|c|c|c|}
\hline $\begin{array}{c}\text { Sample } \\
\text { No. }\end{array}$ & $\underset{(\mathrm{nL} / \mathrm{L})}{\mathrm{CH}_{4}}$ & $\begin{array}{c}\text { Depth } \\
\text { (m) }\end{array}$ & $\begin{array}{c}\text { Sample } \\
\text { No. }\end{array}$ & $\underset{(\mathrm{nL} / \mathrm{L})}{\mathrm{CH}_{4}}$ & $\begin{array}{c}\text { Depth } \\
\text { (m) }\end{array}$ & $\begin{array}{c}\text { Sample } \\
\text { No. }\end{array}$ & $\begin{array}{c}\mathrm{CH}_{4} \\
(\mathrm{~nL} / \mathrm{L})\end{array}$ & $\begin{array}{c}\text { Depth } \\
\text { (m) }\end{array}$ & $\begin{array}{c}\text { Sample } \\
\text { No. }\end{array}$ & $\underset{(\mathrm{nL} / \mathrm{L})}{\mathrm{CH}_{4}}$ & $\begin{array}{c}\text { Depth } \\
\text { (m) }\end{array}$ & $\begin{array}{c}\text { Sample } \\
\text { No. }\end{array}$ & $\begin{array}{c}\mathrm{CH}_{4} \\
(\mathrm{~nL} / \mathrm{L})\end{array}$ & $\begin{array}{c}\text { Depth } \\
\text { (m) }\end{array}$ \\
\hline A-3 & 115,356 & 900 & H-1 & 554 & 380 & $9-1$ & 36.7 & 1,440 & 24-1 & 18.4 & 800 & $42-1$ & 56.5 & 1,100 \\
\hline A-4 & 4.15 & 850 & $\mathrm{H}-2$ & 221 & 330 & $9-2$ & 37.2 & 1,400 & 24-2 & 29.1 & 750 & $42-2$ & 26.2 & 1,050 \\
\hline A-5 & 1,340 & 800 & $\mathrm{H}-3$ & 231 & 280 & $9-3$ & 26.8 & 1,350 & $24-3$ & 17.8 & 700 & $42-3$ & 53.9 & 1,000 \\
\hline A- 6 & 1,158 & 700 & H-4 & 108 & 230 & $9-4$ & 15.8 & 1,300 & $24-4$ & 76.5 & 600 & $42-4$ & 21.4 & 950 \\
\hline \multirow[t]{6}{*}{ A-7 } & 648 & 400 & H-5 & 141 & 180 & $9-5$ & 31.0 & 1,250 & $24-5$ & 39.4 & 500 & $42-5$ & 27.6 & 900 \\
\hline & & & H-6 & 123 & 130 & $9-6$ & 45.5 & 1,000 & $24-6$ & 26.2 & 400 & $42-6$ & 18.4 & 700 \\
\hline & & & H-7 & 55.9 & 80 & $9-7$ & 19.3 & 800 & $24-7$ & 74.4 & 300 & $42-7$ & 30.8 & 500 \\
\hline & & & H-8 & 213 & 50 & $9-8$ & 16.0 & 400 & $24-8$ & 37.7 & 200 & $42-8$ & 24.0 & 300 \\
\hline & & & H-9 & 91.8 & 20 & $9-9$ & 35.9 & 100 & $24-9$ & 52.6 & 100 & & & \\
\hline & & & $\mathrm{H}-10$ & 75.0 & 5 & $9-10$ & 17.1 & 5 & $24-10$ & 33.3 & 5 & & & \\
\hline B-1 & 564 & 1,080 & K-1 & 33.0 & 1,270 & $11-1$ & 27.2 & 530 & 26-1 & 62.3 & 200 & $44-1$ & 70.5 & 160 \\
\hline B-2 & 0.96 & 1,030 & $\mathrm{~K}-2$ & 26.4 & 1,220 & $11-2$ & 44.1 & 500 & $26-2$ & 25.9 & 180 & $44-2$ & 43.2 & 120 \\
\hline B-3 & 394 & 980 & K-3 & 62.9 & 1,170 & $11-3$ & 53.1 & 450 & 26-3 & 40.7 & 160 & $44-3$ & 38.5 & 80 \\
\hline B-4 & 30.4 & 930 & K-4 & 22.3 & 1,120 & $11-4$ & 62.3 & 400 & $26-4$ & 82.4 & 140 & $44-4$ & 35.8 & 40 \\
\hline B-5 & 128 & 880 & K-5 & 9.81 & 1,070 & $11-5$ & 29.8 & 350 & $26-5$ & 21.0 & 120 & $44-5$ & 33.2 & 5 \\
\hline B-6 & 20.4 & 750 & K-6 & 16.6 & 900 & $11-6$ & 7.69 & 300 & $26-6$ & 23.9 & 100 & & & \\
\hline B-7 & 204 & 500 & K-7 & 22.4 & 720 & $11-7$ & 29.4 & 250 & $26-7$ & 19.9 & 50 & & & \\
\hline B-8 & 29.8 & 300 & K-8 & 78.4 & 360 & $11-8$ & 21.6 & 200 & $26-8$ & 21.9 & 30 & & & \\
\hline B-9 & 294 & 100 & K-10 & 9.57 & 5 & $11-9$ & 32.8 & 100 & 26-9 & 38.5 & 15 & & & \\
\hline B-10 & 54.5 & 5 & & & & $11-10$ & 32.0 & 5 & 26-10 & 52.8 & 5 & & & \\
\hline C-1 & 18.0 & 1,150 & L-1 & 48.6 & 1,050 & $13-1$ & 75.3 & 200 & $27-1$ & 10.8 & 135 & $46-1$ & 57.3 & 140 \\
\hline C- 2 & 265 & 1,100 & L-2 & 18.2 & 1,000 & $13-2$ & 48.5 & 180 & $27-2$ & 41.2 & 105 & $46-2$ & 25.8 & 105 \\
\hline C-3 & 11.1 & 1,050 & L-3 & 42.3 & 950 & $13-3$ & 27.3 & 160 & $27-3$ & 64.0 & 70 & $46-3$ & 13.7 & 70 \\
\hline C-4 & 103 & 1,000 & L-4 & 15.8 & 900 & $13-4$ & 46.3 & 140 & $27-4$ & 2.98 & 35 & $46-4$ & 15.5 & 35 \\
\hline C-5 & 19.7 & 850 & L-6 & 31.0 & 700 & $13-5$ & 18.5 & 120 & $27-5$ & 27.3 & 5 & $46-5$ & 5.20 & 5 \\
\hline C-6 & 94.6 & 680 & L-7 & 66.1 & 500 & $13-6$ & 36.9 & 100 & & & & & & \\
\hline C-7 & 34.6 & 510 & L-10 & 40.2 & 5 & $13-8$ & 30.6 & 30 & & & & & & \\
\hline C- 8 & 271 & 340 & & & & $13-9$ & 59.4 & 15 & & & & & & \\
\hline C-9 & 6.15 & 170 & & & & $13-10$ & 34.6 & 5 & & & & & & \\
\hline C- 10 & 160 & 5 & & & & & & & & & & & & \\
\hline D-1 & 53.6 & 1,110 & $1-1$ & 48.9 & 175 & $15-2$ & 20.0 & 900 & $30-1$ & 22.3 & 400 & $48-2$ & 50.4 & 105 \\
\hline D-2 & 8.35 & 960 & $1-2$ & 18.2 & 160 & $15-3$ & 52.2 & 850 & $30-2$ & 26.1 & 350 & 48-4 & 111 & 35 \\
\hline D-3 & 38.3 & 910 & $1-3$ & 43.1 & 140 & $15-4$ & 20.0 & 600 & $30-3$ & 38.8 & 300 & $48-5$ & 50.1 & 5 \\
\hline D-4 & 21.4 & 860 & $1-4$ & 30.3 & 120 & $15-5$ & 16.3 & 500 & $30-4$ & 29.8 & 250 & & & \\
\hline D-5 & 49.7 & 810 & $1-5$ & 47.6 & 100 & $15-6$ & 18.7 & 400 & $30-6$ & 75.4 & 200 & & & \\
\hline D-6 & 20.1 & 700 & $1-6$ & 56.6 & 50 & $15-7$ & 33.9 & 300 & $30-5$ & 56.8 & 150 & & & \\
\hline D-7 & 97.8 & 500 & $1-7$ & 11.0 & 30 & $15-8$ & 35.4 & 200 & $30-7$ & 97.8 & 100 & & & \\
\hline D-8 & 29.4 & 300 & $1-8$ & 29.0 & 15 & $15-9$ & 24.4 & 100 & $30-8$ & 147 & 50 & & & \\
\hline D-9 & 72.0 & 100 & $1-9$ & 29.5 & 5 & $15-10$ & 31.6 & 5 & $30-9$ & 233 & 25 & & & \\
\hline D- 10 & 23.9 & 5 & & & & & & & $30-10$ & 41.1 & 5 & & & \\
\hline E-2 & 11.2 & 970 & $3-1$ & 21.1 & 810 & $18-2$ & 66.8 & 1,700 & $32-1$ & 19.8 & 1,230 & M1-1 & 25.7 & 1,350 \\
\hline E-3 & 68.0 & 920 & $3-2$ & 13.4 & 760 & $18-3$ & 56.5 & 1,650 & $32-2$ & 20.9 & 1,180 & M1-2 & 23.3 & 1,300 \\
\hline E-7 & 80.1 & 500 & $3-3$ & 24.7 & 710 & $18-4$ & 42.7 & 1,600 & $32-3$ & 21.5 & 1,130 & M1-3 & 22.4 & 1,250 \\
\hline E-9 & 68.9 & 100 & $3-4$ & 15.4 & 660 & $18-5$ & 22.4 & 1,300 & $32-6$ & 27.2 & 700 & M1-4 & 33.9 & 1,200 \\
\hline \multirow[t]{5}{*}{ E-10 } & 12.1 & 5 & $3-5$ & 15.5 & 610 & $18-6$ & 19.3 & 1,000 & $32-7$ & 28.4 & 500 & M1-5 & 20.6 & 1,000 \\
\hline & & & $3-6$ & 32.1 & 500 & $18-7$ & 29.0 & 700 & $32-9$ & 18.7 & 100 & M1-7 & 16.3 & 600 \\
\hline & & & 3-7 & 19.4 & 300 & $18-8$ & 40.7 & 400 & $32-10$ & 34.2 & 5 & M1-8 & 33.3 & 400 \\
\hline & & & $3-8$ & 35.6 & 100 & $18-9$ & 47.1 & 100 & & & & M1-9 & 32.8 & 200 \\
\hline & & & $3-9$ & 35.9 & 5 & $18-10$ & 40.8 & 5 & & & & M1-10 & 23.9 & 5 \\
\hline G-1 & 31.8 & 1,010 & $5-1$ & 11.2 & 1,800 & $22-1$ & 25.7 & 1,100 & $34-1$ & 3.52 & 1,500 & M2-1 & 52.9 & 1,320 \\
\hline G-2 & 29.4 & 960 & $5-2$ & 38.1 & 1,750 & $22-2$ & 39.8 & 1,050 & $34-2$ & 9.34 & 1,450 & M2-2 & 8.19 & 1,270 \\
\hline G-3 & 39.0 & 910 & $5-3$ & 16.7 & 1,700 & $22-3$ & 23.5 & 1,000 & $34-3$ & 89.3 & 1,400 & M2-3 & 23.9 & 1,230 \\
\hline G-4 & 22.6 & 860 & $5-4$ & 31.2 & 1,650 & $22-4$ & 10.8 & 950 & $34-4$ & 47.0 & 1,100 & M2-4 & 34.6 & 1,170 \\
\hline G-5 & 22.9 & 810 & $5-6$ & 32.2 & 1,200 & $22-5$ & 43.9 & 900 & $34-5$ & 15.1 & 900 & M2-5 & 17.7 & 1,000 \\
\hline G-6 & 33.0 & 700 & $5-7$ & 13.6 & 800 & $22-6$ & 102 & 800 & $34-6$ & 33.2 & 700 & M2-6 & 19.6 & 800 \\
\hline G-7 & 38.2 & 500 & $5-8$ & 27.2 & 400 & $22-9$ & 39.6 & 200 & $34-7$ & 44.2 & 500 & M2-7 & 36.6 & 600 \\
\hline G-8 & 41.1 & 300 & $5-9$ & 32.8 & 100 & $22-10$ & 74.4 & 5 & $34-8$ & 29.0 & 300 & M2-8 & 17.3 & 400 \\
\hline G-9 & 51.3 & 100 & $5-10$ & 34.62 & 5 & & & & $34-9$ & 29.6 & 100 & M2-9 & 42.1 & 200 \\
\hline G-10 & 1.27 & 5 & & & & & & & $34-10$ & 13.7 & 5 & M2-10 & 31.0 & 5 \\
\hline
\end{tabular}



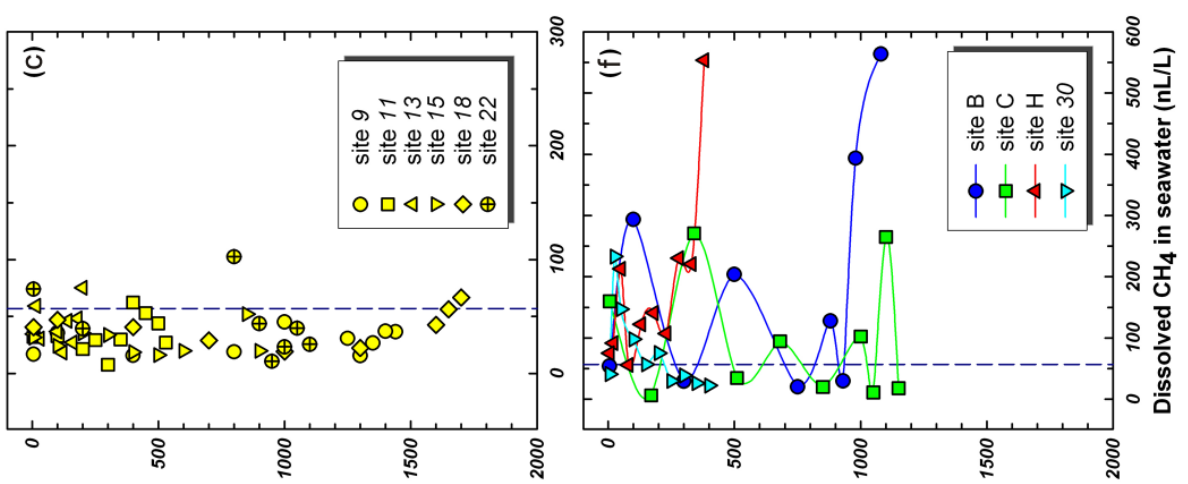

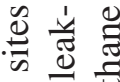

\& $\approx$ ब

o

웅

응

은

을.

光尔

응

年

유 엉

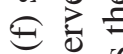

خे

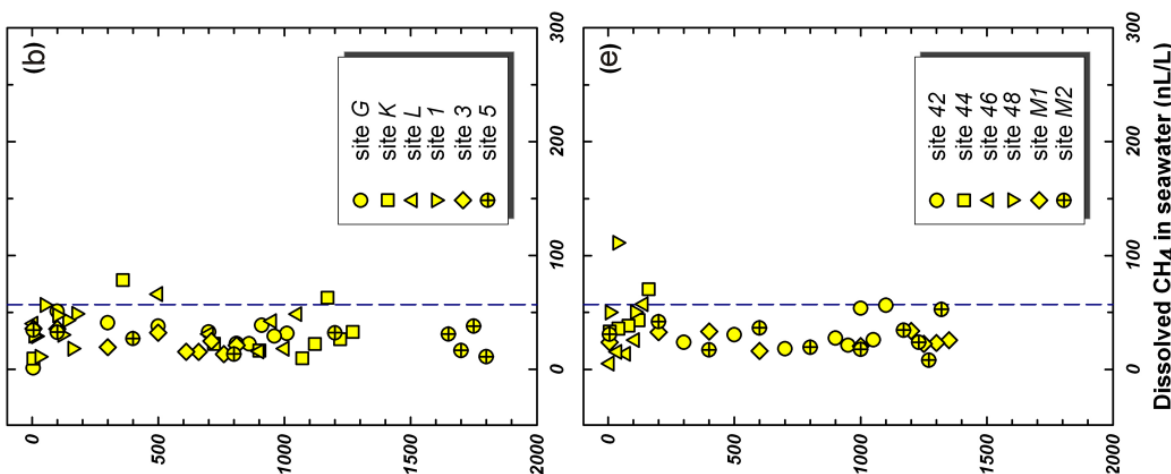

芯造

结每

$\Xi \Xi$

$\stackrel{\Xi}{ \pm}$

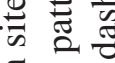

卷 芯

它 \begin{tabular}{c}
1 \\
\hline
\end{tabular}

㐘焉

웜

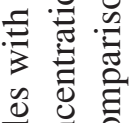

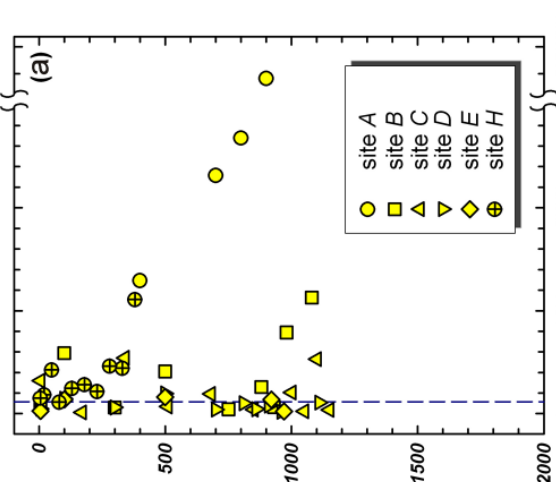

(u) ५วdəp

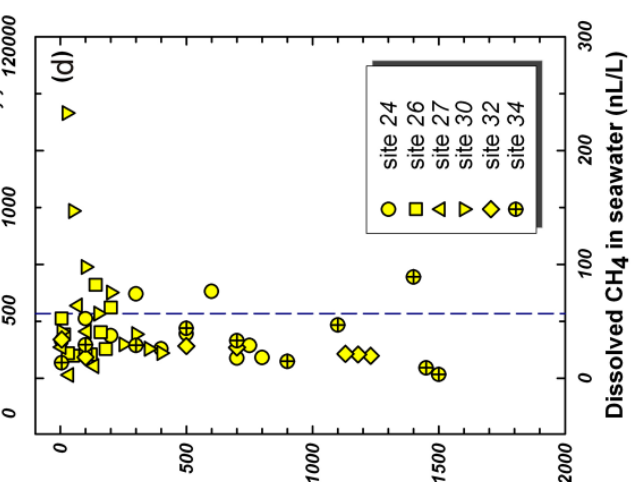

(u) yzdop 
Table 3. Helium concentration and isotopic compositions of dissolved gas of water column samples at representative sites of cruise OR1-765.

\begin{tabular}{|c|c|c|c|c|c|c|c|}
\hline $\begin{array}{l}\text { Sample } \\
\text { No. }\end{array}$ & $\begin{array}{c}\text { Sample } \\
\text { size }(\mathrm{ml})\end{array}$ & $\begin{array}{c}{\left[\mathrm{He}_{4}\right]} \\
(\mathrm{nL} / \mathrm{L})\end{array}$ & ${ }^{4} \mathrm{He} /{ }^{20} \mathrm{Ne}$ & $\begin{array}{c}{ }^{3} \mathrm{He} /{ }^{4} \mathrm{He} \\
\left(* 10^{-6}\right)\end{array}$ & $\begin{array}{c}\text { Error } \\
(\%)\end{array}$ & {$\left[\mathrm{R} / \mathrm{R}_{\mathrm{A}}\right]^{\mathrm{a}}$} & {$\left[\mathrm{R}_{\mathrm{c}} / \mathrm{R}_{\mathrm{A}}\right]^{\mathrm{b}}$} \\
\hline A-1 & 54.5 & 606 & 0.314 & 1.383 & 2.57 & 0.99 & \\
\hline$A-1^{c}$ & 54.5 & 596 & 0.357 & 1.332 & 3.69 & 0.96 & \\
\hline A-2 & 54.5 & 115 & 0.318 & 1.369 & 4.81 & 0.98 & \\
\hline A-3 & 54.0 & 848 & 1.060 & 0.555 & 2.60 & 0.40 & 0.21 \\
\hline A-4 & 54.0 & 172 & 0.436 & 1.145 & 4.88 & 0.82 & \\
\hline A-5 & 55.0 & 126 & 0.369 & 1.187 & 5.36 & 0.85 & \\
\hline A- 6 & 55.5 & 565 & 0.332 & 1.262 & 3.27 & 0.91 & \\
\hline A-7 & 55.0 & 143 & 0.373 & 1.103 & 4.97 & 0.79 & \\
\hline $\mathrm{A} 8$ & 53.0 & 115 & 0.453 & 1.047 & 6.90 & 0.75 & \\
\hline A-9 & 53.5 & 143 & 0.324 & 1.173 & 4.80 & 0.88 & \\
\hline A-10 & 109.0 & 127 & 0.499 & 0.949 & 8.53 & 0.68 & \\
\hline B-1 & 55.5 & 140 & 0.359 & 1.118 & 4.82 & 0.80 & \\
\hline B-2 & 109.5 & 182 & 0.512 & 0.967 & 4.31 & 0.70 & 0.40 \\
\hline B-3 & 112.5 & 176 & 0.439 & 0.986 & 4.19 & 0.71 & \\
\hline B-4 & 112.5 & 151 & 0.450 & 0.985 & 4.44 & 0.71 & \\
\hline C-1 & 54.0 & 634 & 0.368 & 1.172 & 3.95 & 0.84 & \\
\hline C-4 & 111.0 & 177 & 0.381 & 1.099 & 5.78 & 0.79 & \\
\hline C-10 & 109.0 & 164 & 0.370 & 1.184 & 5.07 & 0.85 & \\
\hline D-2 & 111.0 & 182 & 0.384 & 1.225 & 5.68 & 0.88 & \\
\hline D-10 & 112.0 & 174 & 0.388 & 1.235 & 4.52 & 0.89 & \\
\hline E-2 & 115.0 & 167 & 0.298 & 1.253 & 4.84 & 0.97 & \\
\hline E-3 & 55.0 & 162 & 0.401 & 1.264 & 5.33 & 0.91 & \\
\hline G-1 & 110.0 & 183 & 0.453 & 1.084 & 3.46 & 0.78 & \\
\hline G-3 & 115.0 & 177 & 0.414 & 1.127 & 2.67 & 0.81 & \\
\hline G-10 & 50.0 & 181 & 0.455 & 1.170 & 3.89 & 0.84 & \\
\hline $\mathrm{H}-3$ & 110.0 & 286 & 0.375 & 1.278 & 5.32 & 0.92 & \\
\hline $18-4$ & 115.0 & 148 & 0.393 & 1.110 & 5.78 & 0.80 & \\
\hline
\end{tabular}

a. Measured ${ }^{3} \mathrm{He} /{ }^{4} \mathrm{He}$ ratio normalized to the air ratio $\left(R_{A}=1.39 \times 10^{-6}\right)$.

b. Air corrected ratio $\left(\mathrm{R}_{\mathrm{c}}\right)$, assuming all the measured neon concentration are derived from air saturated water (Poreda and Craig 1989). Note that only those samples with larger ${ }^{4} \mathrm{He} /{ }^{20} \mathrm{Ne}$ value can be corrected.

c. Duplicate analysis.

Compared with the composition of air-saturated water, [He] $=37.4-45.5 \mathrm{~nL} \mathrm{~L}^{-1}$ (Inguaggiato and Rizzo 2004; Sano and Takahada 2005) and ${ }^{3} \mathrm{He} /{ }^{4} \mathrm{He}=0.98 R_{A}$ (Benson and Krause Jr. 1980), the results show distinct excess helium and lower ${ }^{3} \mathrm{He} /{ }^{4} \mathrm{He}$ ratios.

Based on the three-component plot of ASW (air-saturated water)- Crust-Mantle shown in Fig. 4, the dissolved gases studied here require a crustal component mixed with the ASW end 
member to explain their composition. The air-corrected ${ }^{3} \mathrm{He} /{ }^{4} \mathrm{He}$ ratios are $0.2-0.4 R_{A}$ (Table 3), which is similar to gas composition of on-shore mud volcanoes. The well defined mixing trend in Fig. 4 indicates that a contribution more than $70 \%$ of the crustal component, compositionally similar to the composition of on-shore mud volcanoes in SW Taiwan, is required to account for the helium isotopic data. This suggests that they may share the same or a similar gas source from crustal sediments. Note that the helium isotopic composition of gases from the mud volcanoes of SW Taiwan are very different to those from mud volcanoes and submarine hot springs in SE Taiwan, which exhibit significant contributions of a mantle component (Fig. 4; Yang et al. 2003a, b).

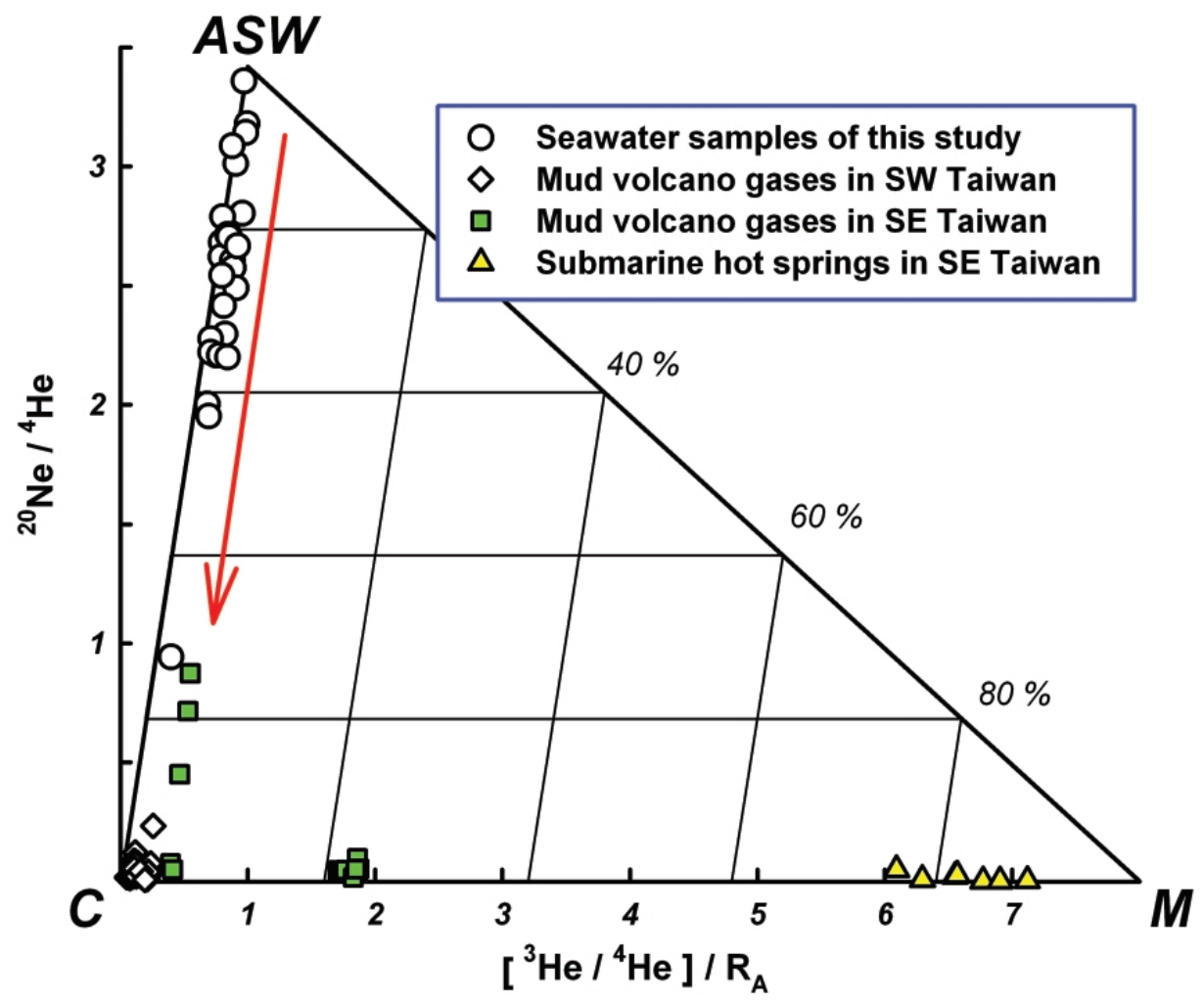

Fig. 4. Three-component plot for helium isotopic data. Available data for onshore mud volcanoes and submarine hot springs in SE Taiwan are also plotted for comparison. Data from Yang et al. (2003a, b). Arrow indicates the mixing trend for seawater samples from ASW component toward the crustal component. See text for further discussion for their gas sources. ASW: air-saturated water; C: crust; M: mantle component. 


\subsection{Methane Venting Sites with High Methane and High Helium Concentration}

Although high methane and helium concentrations are observed at some sites, they do not show consistent increasing trends (Fig. 5). Suess et al. (1999) suggested that the decoupling between maxima of methane and helium is due to bubble transport of methane. Figure 5 shows that a leaking problem might occur for both helium and methane measurement either during samples handling or storage before analysis. However, a clearly increasing trend for both sites $\mathrm{A}$ and $\mathrm{H}$ can be obtained, suggesting a deep venting source for those sites at least.

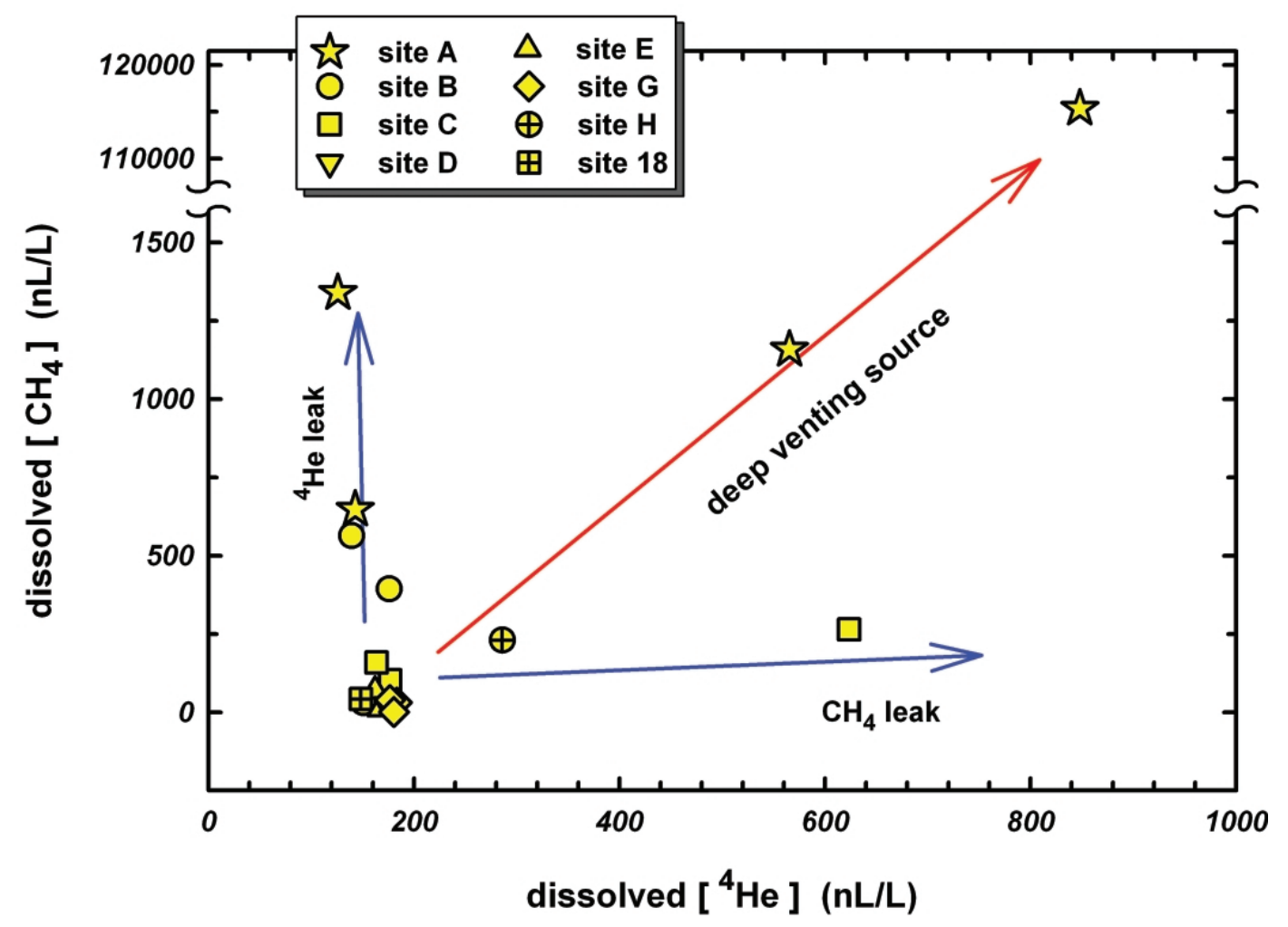

Fig. 5. Dissolved $\mathrm{CH}_{4}$ concentration vs. He concentration plotted for all samples. There are decoupled enrichment trends for methane and helium, which may be due to leak problems. For sites A and B, there are significant helium leaks for some samples; and there is one sample with a methane leak for site C. However, there is a clear increasing trend for both helium and methane concentrations, indicating a deep venting source, for site A. 
Figure 6 shows the profiles of helium and methane data at sites A, B, and C. Although a few methane data for shallow depths at site A are missing due to inappropriate sample handling on board, a distinctly increasing trend for both dissolved methane and helium can be observed. We cannot see this trend for both methane and helium at sites B and C due to a leaking problem (as demonstrated in Fig. 5). The highest helium and methane concentrations, 848 and $115356 \mathrm{~nL} \mathrm{~L}^{-1}$, respectively, were obtained near the bottom of site A.

The degassing trace gases, like helium and radon, are usually carried by their carrier gases and emitted through fractures/faults and/or by hydrothermal activity from deep sources onto the surface of the Earth (e.g., Yang et al. 2003b, 2005a). In seawater samples taken at greater depths in general contain higher concentrations of dissolved gas, which may simply be due to the higher solubility of gases at lower temperature (e.g., Takahata et al. 2004; Sano and Takahata 2005). Takahata et al. (2004) calculated excess noble gases in seawater could be up to $9.6 \%$, however, there was no relationship between the depth and the anomaly. This is clearly not the

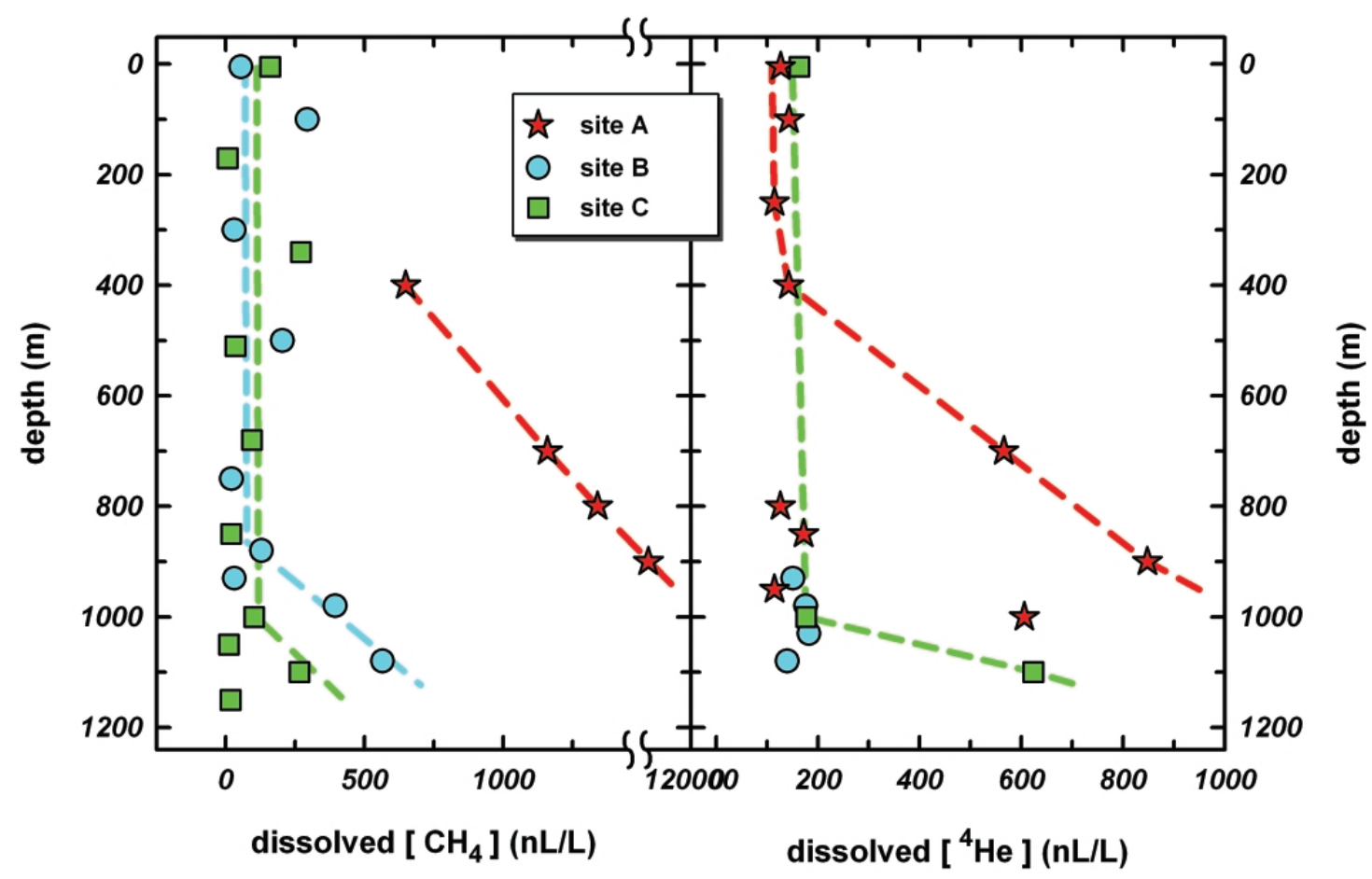

Fig. 6. Methane and helium profiles at sites A, B, and C. Dashed line shows the inferred original profile after skip those data with leakage problems. Note that the maximum concentrations for both helium and methane occurred near the seafloor. 
case with our data and cannot be explained simply by the different solubility of gases at different depths. The maximum concentration near the sea bottom is several orders of magnitude higher than the background levels in seawater. An injection source from the seabed is necessary to account for the data obtained in this study. Therefore, a methane-rich source, with high helium gas, is actively venting at site A.

Calculated $\mathrm{CH}_{4} \beta \mathrm{He}$ ratio for the sample A-3, which exhibits the highest methane and helium concentrations and is able to calculate the excess concentration of ${ }^{4} \mathrm{He}$ and ${ }^{3} \mathrm{He}$ in the sample, is $488 \times 10^{6}$. It is similar to the composition of gases from geothermal wells in the Momotombo system of Central America (Snyder et al. 2003). The value is much higher than those of methane-rich natural gases in hydrothermal areas $\left(1-50 \times 10^{6}\right)$ (e.g., Wakita and Sano 1983; Snyder et al. 2003), Snyder et al. (2003) concluded that there is an addition of crustal methane to the magmatic volatile component. Extremely high methane concentrations were also found in the bottom water and cored sediments from this site (Chuang et al. 2006). Carbon isotopic compositions of methane gases from this site range from - 74.6 to $-74.7 \%$ and the $\mathrm{CH}_{4} / \mathrm{C}_{2} \mathrm{H}_{6}$ ratios from 2729 to 3008 (Chuang 2006). This indicates they are mainly biogenic gas source in origin. Although the venting gas could be derived from the deep gas reservoir, considering the possible occurrence of gas hydrates in this area (Liu et al. 2006), the venting methane is most likely derived from the dissociation of underlain gas hydrates.

\section{CONCLUDING REMARKS}

Based on the results of our systematic gas analysis for water column from the potential gas hydrate areas of offshore southwestern Taiwan, the following points emerge:

1. Distinct excess methane and helium in seawater samples is observed, especially for sites in the active margin of SW Taiwan.

2. No high radon concentrations in seawater were found even at the sites with high methane and helium concentrations.

3. Excess methane but not helium occurred at shallow depths at some sites. This could be due to bacteria activity in surface seawater.

4. The helium isotopic data of the seawater samples suggest that the dissolved gases are the result from mixing between air-saturated water and a crustal gas component.

5. The highest concentrations of both helium and methane were found in deep water near the seafloor. This is considered as evidence for the presence of a methane venting source, may fed from dissociation of gas hydrates and/or a deeper gas reservoir.

Acknowledgments We thank the Captain and crew of Ocean Research Vessel I, and all assistants and students for their help in collecting samples and conducting on board analysis. Mrs. B. W. Lin, W. L. Hong, and C. C. Fu helped in the analysis of helium and radon gases; and Ms. H. F. Lee for figure drawing. Drs. Y. Sano, Y. J. Lee, and U. Knittel gave critical comments and improved the manuscript. This paper presents part of results of the gas hydrate exploration project supported by the Central Geological Survey of Taiwan, ROC (TFY/ 5226902000-06-93-02, 5226902000-05-94-02, and 5226902000-05-95-02). 


\section{REFERENCES}

Benson, B. B., and D. Krause Jr., 1980: Isotope fractionation of helium during solution: a probe for the liquid state. J. Solut. Chem., 9, 895-909.

Chao, H. C., and C. F. You, 2006: Distribution of B, Cl and their isotopes in pore waters separated from gas hydrate potential areas, offshore southwestern Taiwan. Terr. Atmos. Ocean. Sci., 17, 961-979.

Chen, C. T. A., and H. C. Tseng, 2006: Abnormally high $\mathrm{CH}_{4}$ concentrations in seawater at mid-depths on the continental slopes of the northern South China Sea. Terr. Atmos. Ocean. Sci., 17, 951-959.

Chi, W. C., D. L. Reed, C. S. Liu, and N. Lunberg, 1998: Distribution of the bottom simulating reflector in the offshore Taiwan collision zone. Terr. Atmos. Ocean. Sci., 9, 779-793.

Chiu, J. K., W. H. Tseng, and C. S. Liu, 2006: Distribution of gassy sediments and mud volcanoes offshore southwestern Taiwan. Terr. Atmos. Ocean. Sci., 17, 703-722.

Chow, J., J. S. Lee, R. Sun, C. S. Liu, and N. Lundberg, 2000: Characteristics of the bottom simulating reflectors near mud diapirs: offshore southwestern Taiwan. Geo-Mar. Lett., 20, 3-9.

Chuang, P. C., 2006: Gas geochemistry study in gas hydrate potential area offshore SW Taiwan. Master Thesis, Natl. Taiwan Univ., Taiwan, 83 pp. (in Chinese)

Chuang, P. C., T. F. Yang, S. Lin, H. F. Lee, T. F. Lan, W. L. Hong, C. S. Liu, J. C. Chen, and Y. Wang, 2006: Extremely high methane concentration in bottom water and cored sediments from offshore southwestern Taiwan. Terr. Atmos. Ocean. Sci., 17, 903-920.

Chyi, L. L., T. J. Quick, T. F. Yang, and C. H. Chen, 2005: Soil gas radon spectra and earthquakes. Terr. Atmos. Ocean. Sci., 16, 763-774.

Cigolini, C., G. Gervino, R. Bonetti, F. Conte, M. Laiolo, D. Coppola, and A. Manzoni, 2005: Tracking precursors and degassing by radon monitoring during major eruptions at Stromboli Volcano (Aeolian Islands, Italy). Geophys. Res. Lett., 32, doi: 10.1029/ 2005 GL022606.

Colwell, F., R. Matsumoto, and D. Reed, 2004: A review of the gas hydrates, geology, and biology of the Nankai Trough. Chem. Geol., 205, 391-404.

Fu, C. C., T. F. Yang, V. Walia, and C. H. Chen, 2005: Reconnaissance of soil gas composition over the buried fault and fracture zone in southern Taiwan. Geochem. J., 39, 427-439.

Horng, C. S., and K. H. Chen, 2006: Complicated magnetic mineral assemblages in marine sediments offshore of southwestern Taiwan: possible influence of methane flux on the early diagenetic process. Terr. Atmos. Ocean. Sci., 17, 1009-1026.

Huang, C. Y., W. Y. Wu, C. P. Chang, S. Tsao, P. B. Yuan, C. W. Lin, and K. Y. Xia, 1997: Tectonic evolution of accretionary prism in the arc-continent collision terrain of Taiwan. Tectonophysics, 281, 31-51.

Huang, C. Y., C. W. Chien, M. Zhao, H. C. Li, and Y. Iizuka, 2006: Geological study of active cold seeps in the syn-collision accretionary prism Kaoping slope off SW Taiwan. Terr. Atmos. Ocean. Sci., 17, 679-702.

Imme, G., S. La Delfa, S. Lo Nigro, D. Morelli, and G. Patane, 2006: Soil radon concentration 
and volcanic activity of Mt. Etna before and after the 2002 eruption. Radiat. Meas., 41, 241-245.

Inguaggiato, S., and A. Rizzo, 2004: Dissolved helium isotope ratios in ground-waters: a new technique based on gas-water re-equilibration and its application to Stromboli volcanic system. Appl. Geochem., 19, 665-673.

Jiang, W. T., J. C. Chen, B. J. Huang, C. J. Chen, Y. T. Lee, P. R. Huang, C. C. Lung, and S. W. Huang, 2006: Mineralogy and physical properties of cored sediments from the gas hydrate potential area of offshore southwestern Taiwan. Terr. Atmos. Ocean. Sci., 17, 981-1007.

Kvenvolden, K. A., 1998: A primer on the geological occurrence of gas hydrate. In: Henriet, J. P., and J. Mienert (Eds.), Gas hydrates: relevance to world margin stability and climate change, Geol. Soc. London, Spec. Publ., 137, 9-30.

Kvenvolden, K. A., and T. D. Lorenson, 2000: Methane and other hydrocarbon gases in sediment from the southeastern North American continental margin. In: Paull, C. K. et al. (Eds.), Proceedings of the Ocean Drilling Program, Scientific Results, 164, 29-36.

Lammers, S., and E. Suess, 1994: An improved head-space analysis method for methane in seawater. Mar. Chem., 47, 115-125.

Lee, H. F., T. F. Yang, T. F. Lan, S. R. Song, and S. Tsao, 2005: Fumarolic gas composition of the Tatun Volcano Group, northern Taiwan. Terr. Atmos. Ocean. Sci., 16, 843-864.

Lin, S., W. C. Hsieh, Y. C. Lim, T. F. Yang, C. S. Liu, and Y. Wang, 2006: Methane migration and its influence on sulfate reduction in the Good Weather Ridge region, South China Sea continental margin sediments. Terr. Atmos. Ocean. Sci., 17, 883-902.

Liu, C. S., B. Deffontaines, C. Y. Lu, and S. Lallemand, 2004: Deformation patterns of an accretionary wedge in the transition zone from subduction to collision offshore southwestern Taiwan. Mar. Geophys. Res., 25, 123-137.

Liu, C. S., I. L. Huang, and L. S. Teng, 1997: Structure features off southwestern Taiwan. Mar. Geol., 137, 305-319.

Liu, C. S., P. Schnürle, Y. Wang, S. H. Chung, S. C. Chen, and T. H. Hsiuan, 2006: Distribution and characters of gas hydrate offshore of southwestern Taiwan. Terr. Atmos. Ocean. Sci., 17, 615-644.

Lorenson, T. D., and T. S. Collett, 2000: Gas content and composition of gas hydrate from sediments of the southeastern North American continental margin. In: Paull, C. K. et al. (Eds.), Proceedings of the Ocean Drilling Program, Scientific Results, 164, 37-46.

Lupton, J. E., E. T. Baker, N. Garfield, G. J. Massoth, R. A. Feely, J. P. Cowen, R. R. Green, and T. A. Rago, 1998: Tracking the evolution of a hydrothermal event plume with a RAFOS neutrally buoyant drifter. Science, 280, 1052-1055.

Matsumoto, R., 2004: Special issue on Gas hydrate in Nankai Trough, Japan - Preface. Resour. Geol., 54, 102.

Oung, J. N., C. Y. Lee, C. S. Lee, and C. L. Kuo, 2006: Geochemical study on hydrocarbon gases in seafloor sediments, southwestern offshore Taiwan - implications in the potential occurrence of gas hydrates. Terr. Atmos. Ocean. Sci., 17, 921-931.

Ozima, M., and F. A. Podosek, 2002: Noble gas geochemistry, $2^{\text {nd }}$ Ed., Camb. Univ. Press, Camb., 286 pp. 
Pecher, I. A., 2002: Gas hydrates on the brink. Nature, 420, 622-623.

Poreda, R., and H. Craig, 1989: Helium isotope ratios in Circum-Pacific volcanic arcs. Nature, 338, 473-478.

Sano, Y., and N. Takahata, 2005: Measurement of noble gas solubility in seawater using a quadrupole mass spectrometer. J. Oceanogr., 61, 465-473.

Schlosser, P., and G. Winckler, 2002: Noble gases in ocean waters and sediments. In: Porcelli, D., C. J. Ballentine, and R. Wieler (Eds.), Noble gases in geochemistry and cosmochemistry, reviews in mineralogy \& geochemistry, 47, 701-730.

Schnürle, P., T. H. Hsiuan, and C. S. Liu, 1999: Constrains on free gas and gas hydrate bearing sediments from multi-channel seismic data, offshore southwestern Taiwan. Petrol. Geol. Taiwan, 33, 21-42.

Schnürle, P., T. H. Hsiuan, T. K. Wang, K. MacIntosh, C. S. Liu, D. Reed, and Y. Nakamura, 2002: Characteristics of gas hydrate and free gas offshore southwestern Taiwan: preliminary results from a combined seismic reflection/refraction analysis. Petrol. Geol. Taiwan, 35, 1-34.

Schubert, M., P. Pena, M. Balcazar, R. Meissner, A. Lopez, and J. H. Flores, 2005: Determination of radon distribution patterns in the upper soil as a tool for the localization of subsurface NAPL contamination. Radiat. Meas., 40, 633-637.

Scranton, M., and P. G. Brewer, 1978: Consumption of dissolved methane in the deep ocean. Limnol. Oceanogr., 15, 883-886.

Segovia, N., M. A. Armienta, C. Valdes, M. Mena, J. L. Seidel, M. Monnin, P. Pena, M. B. E. Lopez, and A. V. Reyes, 2003: Volcanic monitoring for radon and chemical species in the soil and in spring water samples. Radiat. Meas., 36, 379-383.

Shyu, C. T., Y. J. Chen, S. T. Chiang, and C. S. Liu, 2006: Heat flow measurements over bottom simulating reflectors, offshore southwestern Taiwan. Terr. Atmos. Ocean. Sci., 17, 845-869.

Sloan, E. D. Jr., 1998: Physical/chemical properties of gas hydrates and application to world margin stability and climatic change. In: Henriet, J. P., and J. Mienert (Eds.), Gas hydrates: relevance to world margin stability and climate change. Geol. Soc., London, Spec. Publ., 137, 31-50.

Snyder, G., R. Poreda, U. Fehn, and A. Hunt, 2003: Sources of nitrogen and methane in Central American geothermal settings: Noble gas and ${ }^{129} \mathrm{I}$ evidence for crustal and magmatic volatile components. Geochem. Geophys. Geosyst., 4, doi: 10.1029/ 2002 GC000363.

Suess, E., M. E. Torres, G. Bohrmann, R. W. Collier, J. Greinert, P. Linkea, G. Rehder, A. Trehu, K. Wallmann, G. Winckler, and E. Zuleger, 1999: Gas hydrate destabilization: enhanced dewatering, benthic material turnover and large methane plumes at the Cascadia convergent margin. Earth Planet. Sci. Lett., 170, 1-15.

Takahata, N., T. Watanabe, K. Shirai, M. Nishizawa, and Y. Sano, 2004: Helium isotopes of seawater in adjacent sea of Nansei Islands, Southwest Japan. Geochem. J., 38, 593-600.

Teng, L. S., 1990: Late Cenozoic arc-continent collision in Taiwan. Tectonophysics, 183, 57-76.

Wakita, H., and Y. Sano, 1983: ${ }^{3} \mathrm{He} /{ }^{4} \mathrm{He}$ ratios in $\mathrm{CH}_{4}$-rich natural gases suggest magmatic origin. Nature, 305, 792-794. 
Walia, V., T. C. Su, C. C. Fu, and T. F. Yang, 2005a: Spatial variations of radon and helium concentrations in soil gas across the Shan-Chiao fault, Northern Taiwan. Radiat. Meas., 40, 513-516.

Walia, V., H. S. Virk, T. F. Yang, S. Mahajan, M. Walia, and B. S. Bajwa, 2005b: Earthquake prediction studies using radon as a precursor in N-W Himalayas, India: a case study. Terr. Atmos. Ocean. Sci., 16, 775-804.

Wood, W. T., J. F. Gettrust, N. R. Chapman, G. D. Spence, and R. D. Hyndman, 2002: Decreased stability of methane hydrate in marine sediments owing to phase-boundary roughness. Nature, 420, 656-660.

Yang, T. F., C. H. Chen, R. L. Tien, S. R. Song, and T. K. Liu, 2003a: Remnant magmatic activity in the Coastal Range of East Taiwan after arc-continent collision: fission-track date and ${ }^{3} \mathrm{He} /{ }^{4} \mathrm{He}$ ratio evidence. Radiat. Meas., 36, 343-349.

Yang, T. F., C. Y. Chou, C. H. Chen, L. L. Chyi, and J. H. Jiang, 2003b: Exhalation of radon and its carrier gases in SW Taiwan. Radiat. Meas., 36, 425-429.

Yang, T. F., G. H. Yeh, C. C. Fu, C. C. Wang, T. F. Lan, H. F. Lee, C. H. Chen, V. Walia, and Q. C. Sung, 2004: Composition and exhalation flux of gases from mud volcanoes in Taiwan. Environ. Geol., 46, 1003-1011.

Yang, T. F., T. F. Lan, H. F. Lee, C. C. Fu, P. C. Chuang, C. H. Lo, C. H. Chen, C. T. A. Chen, and C. S. Lee, 2005a: Gas compositions and helium isotopic ratios of fluid samples around Kueishantao, NE offshore Taiwan and its tectonic implications. Geochem. J., 39, 469-480.

Yang, T. F., V. Walia, L. L. Chyi, C. C. Fu, C. H. Chen, T. K. Liu, S. R. Song, C. Y. Lee, and M. Lee, 2005b: Variations of soil radon and thoron concentrations in a fault zone and prospective earthquakes in SW Taiwan. Radiat. Meas., 40, 496-502.

Yang, T. F., C. C. Fu, V. Walia, C. H. Chen, L. L. Chyi, T. K. Liu, S. R. Song, M. Lee, C. W. Lin, and C. C. Lin, 2006: Seismo-geochemical variations in SW Taiwan: multi-parameter automatic gas monitoring results. Pure Appl. Geophys., 163, 693-709.

Yang, T. F., P. C. Chuang, S. Lin, J. C. Chen, Y. Wang, and S. H. Chung, 2006: Methane venting in gas hydrate potential area offshore of SW Taiwan: evidence of gas analysis of water column samples. Terr. Atmos. Ocean. Sci., 17, 933-950. 